Itinéraires Itinéraires

Littérature, textes, cultures

\title{
Immersion and distance in fictional worlds
}

\section{Thomas Pavel}

\section{OpenEdition}

\section{Journals}

Electronic version

URL: http://journals.openedition.org/itineraires/2183

DOI: 10.4000/itineraires.2183

ISSN: 2427-920X

\section{Publisher}

Pléiade

\section{Printed version}

Date of publication: 1 May 2010

Number of pages: 99-109

ISBN: 978-2-296-11224-7

ISSN: $2100-1340$

Electronic reference

Thomas Pavel, «Immersion and distance in fictional worlds », Itinéraires [Online], 2010-1 | 2010, Online since 01 May 2010, connection on 20 April 2019. URL : http://journals.openedition.org/ itineraires/2183; DOI : 10.4000/itineraires.2183

\section{(c) (1) $\Theta$}

Itinéraires est mis à disposition selon les termes de la licence Creative Commons Attribution - Pas d'Utilisation Commerciale - Pas de Modification 4.0 International. 


\title{
Immersion and distance in fictional worlds
}

\begin{abstract}
Based on the notion of immersion as developed by Jean-Marie Schaeffer, the article examines the readers' relationship with fictional worlds. It compares the temporal succession of the exposition, the knot, the adventures, and the denouement of a plot with the spatial effects of visual perspective in a painting. The reader or spectator easily adopts the maxims governing fictional characters and the space of Goods within which they act. Immersion doesn't however prevent the reader from discovering, beyond these maxims and Goods, their intangible source, which is also the source of aesthetic wonder.
\end{abstract}

Keywords : reading, fiction, perspective, values, wonder Mots clés : lecture, fiction, perspective, valeurs, émerveillement

\section{Immersion in the fictional Umwelt}

Literary worlds are conceived to dazzle their visitors, to enrapture them. Literature may seem to imitate the actual world, and in some sense it does. Yet, the impression of resemblance to the actual world, or, to be more precise, the impression that literature has something important to convey about the actual world is generated indirectly, by way of a process in which illusion (or simulation, acting) and seduction (or enticement) play a crucial role. We do not observe fictional worlds from the outside, the way an astronomer from Sirius would look at our planet, but are invited to consider them as a human habitat in which living human beings pursue projects, struggle against hurdles, reach happiness or are defeated. Built for the human eye, fictional worlds aim at persuading our mind that it engages them as living experience. To achieve this illusion, they need to entice their public to let itself be absorbed in it (« to suspend its disbelief ») and answer its challenges properly, if vicariously ${ }^{1}$.

1. Kendal Walton, Mimesis and Make Believe, Cambridge, Mass., Harvard University Press, 
As a spectator of Hamlet, I suspend my disbelief in ghosts and find in myself a way to adhere to the idea that killing a tyrant is a justifiable act. When in Le Cid, I witness a nobleman slap another one and I hear that the only proper way of answering the insult is a duel, I find myself adhering, participating - provisionally and vicariously - to the code of honor that governs the characters' lives.

But my participation is not limited to my adhering (fictionally, if one follows Kendall Walton) to the actions and norms displayed in the play I read or watch. I am not simply a subscriber to a variety of « is » and « ought to » propositions, a prudent subscriber, I may add, if I manage to hold on to my awareness that all these descriptions and normative propositions belong to a work of fiction.

Active sympathy plays a major role. Taking the rather unusual example of watching a man being tortured on the rack, Adam Smith writes :

\footnotetext{
By the imagination we place ourselves in his situation, we conceive ourselves enduring all the same torments, we enter as it were into his body, and become in some measure the same person with him, and thence form some idea of his sensations, and even feel something which, though weaker in degree, is not altogether unlike them ${ }^{2}$.
}

Replacing life by artistic representation does not impair sympathy. Observing how Hamlet discovers that his father was murdered by his uncle triggers in the spectator a similar reaction. I enter, as it were, into the Prince's torments : I look at Hamlet less and less through my own eyes and increasingly behold the world in which Hamlet lives, seeing it through his eyes, as if I were somehow uncannily close to him.

In order for me to reach this stage, I must let my attention be captured by the play and directed towards the states of affairs that unfold in front of me. I must orient myself in the multiplicity of situations, characters, and maxims that make up the play.

Direct, orient - these are terms that designate movement. Not just any movement, but a movement that either spontaneously or reflectively is brought to fit the conditions in which it takes place. In other words : an adequate movement, adequate, that is, to the task of partaking in the world opened by Shakespeare's play.

Something not unlike the effect of pictorial perspective is at work here.

In Masaccio's Trinity at Santa Maria Novella in Florence, the single point towards which the orthogonal lines of the vault converge, a point which lies below the Holy Cross, invites me to stand at an optimal distance 
from the painting and grasp it as a space rather than a surface, to feel, in other words, as though perceptually I belonged to the area opened up by the fresco. In a more complex intervention, Poussin's Ecstasy of St Paul (paris, Louvre) not only includes me in the space of the painting, but the direction of light, the dynamics of color and the positions of the bodies make me feel that I am moving upwards, enticed by the flood of light ${ }^{3}$.

And just as in painting the vanishing point and the dynamics of light and color allure and direct my gaze, absorbing me, as it were, in the pictorial space, narratives and plays activate my mental ability to get involved in their fictional world, grasp its challenges and gauge the stakes of action.

Lessing's distinction between the ways in which visual arts activate our spatial sense and narratives appeal to our sense of time is certainly crucial. Yet, a mere reference to temporality is not enough. When long before Lessing, Aristotle spoke of the beginning, the middle, and the end of a story, he made a deeper statement than it seems at first sight, a statement about the perspective of action, since the beginning, not unlike the sense of space in painting, awakens my ability, I'd even say an urge, to attend the fictional world; the middle, not unlike color and the positions of bodies in painting, strengthen my sense of participation; the end, similar to the sense of the whole in a painting, seals the world of the story, giving it a distinct, enduring configuration. When, in addition, Aristotle stated that tragedy must imitate (represent) actions that are terrifying or pitiable, thus causing fear and pity, he referred, in his usual allusive style, to the elements that capture my attention and orient me, to the feelings that pull me towards the represented world and keep me there.

Two aspects of this magnetic attraction need to be distinguished. One is the temporal equivalent of a picture's lines that converge towards the vanishing point - that is, the elements that pull me towards the narrative world and invite me to partake in the action it hosts. The beginning of a story or of a play does just this, not as much through the presentation of the initial facts in and of themselves, as by implicitly stating the cause or, more exactly, the circumstantial cause that triggers future events and thus generates a «rush for action» that sweeps me away. An unusual event, a lack, an obstacle, a transgression excite my aptitude for grasping the need for further moves as effectively as the lines leading to the vanishing point in Masaccio's Trinity make my eye feel caught in the spatial depth.

In Hamlet, the visits of the Ghost trigger in me not only fear and curiosity, but also an explosion of hypotheses, expectations and projections of possible courses of actions, in close touch and often in competition with Hamlet's own musings and concrete steps. By portraying a striking event

3. The examples come from Martin Kemp, The Science of Art, New Haven, Yale University Press, 1999. 
as cause for further action, the beginning of the play initiates a temporal marathon, in which I naturally, irresistibly, feel myself included.

And just as the lines in Masaccio's painting lead to an invisible point that is clearly felt not only as present, but also as commanding the spatial structure, the temporal perspective of Hamlet inescapably leads towards the tragedy's mainspring or, as neo-classicist pœtics called it, the plot's knot, that is the true source of the conflict, in this case the murder of Hamlet's father by his uncle Claudius, an action from which virtually everything that happens in the play derives, directly or indirectly.

In most paintings, the vanishing point does not coincide with the place where the maximal dramatic effect lies. In Masaccio's Trinity, the eye is mesmerized by grandiose vault that lies above the cross and, in its middle, by the contrast between the calm, self-possessed, face of God the Father and the dead face of crucified Jesus. In the temporal perspective of the play, the rush of actions leads to a climax or high point, which retroactively brings together all expectations, projects, actions and reactions in the play. This is perhaps the moment when Laertes tells Hamlet that the sword that pricked him before he grabbed it in the heat of their fight, as well as the cup from which Gertrude just drank, has been poisoned by the order of the King. Hamlet shouts : " Then, venom, do thy work », stabs Claudius and forces him to drink the poisonous potion prepared for Hamlet. The issues raised by the play - the murder of Hamlet's father, Hamlet's attempt to separate Gertrude from Claudius, Claudius' various plots to get rid of Hamlet, the death of polonius and Ophelia that Laertes wants, treacherously, to avenge - are all brought to a sudden, swift resolution. Neo-classicist pœetics called this moment denouement - a term that comes from the French dénouer (« to untie, to untangle »), thus continuing the metaphor of the knot that ties together the threads of the action.

In Masaccio's painting, a spectacular contrast opposes the forceful look of God the Father to the exhaustion of Jesus' hanging head. The Holy Virgin, standing at the left, lifts her hand, inviting us to contemplate the two divine faces, while St. John, at the right, prays raising his eyes towards them. These starkly different faces embody the culmination of the painting and, at the same time, its resolution. The gesture of the Holy Virgin and the eyes of St. John seem to say : " This is what you all should see and remember ». Similarly, the frenzy of killings in Hamlet's fifth act brings the story to an end, making it worthy of being told, as Hamlet knows well when he asks Horatio : « Tell my story. »

« Tell my story » - this is something that any of us who has attended or read the tragedy could by now do. We are not in the play - just as we are not inside the space evoked by Masaccio's Trinity. But after looking at the fresco for a while, after keeping up with the play's action we know and remember them as though we belonged indeed to the space of the Trinity and to the court of Denmark. 
Does this sense of belonging require from us a clear-cut separation from the actual world - the crowded corner of Santa Maria Novella, the seat in the theater? I don't think so. We certainly are no more than spectators and at no point we fully forget it. If anyone in the theater shouts « Hamlet, be careful, the sword is poisoned! » the audience would quickly silence him. But our awareness that the events on the wall of the chapel or on the stage do not take place in our actual everyday world fails to keep us at a truly safe distance from them. We don't merely contemplate these events, enjoying our detachment from the sorrows of this world - the death of Jesus, the tragedy of Hamlet -, content to savor the glow of the spectacle. This glow, moreover, isn't exclusively created by the artistic splendor of the painting and of the play. And our experience of these and other works of art cannot be described as a purely aesthetic one, the illusion created by perspective - spatial and temporal - being just a means to enhance our calm enjoyment.

The force with which the spatial and temporal perspectives attract us into the space of the painting and the action of the play suggests that, far from contemplating these works of art and literature from a position of detachment, freed from the sorrows of this world, we find ourselves willynilly, one could even say thoughtlessly, immersed in the world evoked by $\operatorname{art}^{4}$. We are spectators, yet we are not true outsiders, we contemplate, but through involvement and contagion. We have no actual power to modify what happens in the fictional world, but we still project our desires, exercise our will, even though, in fact, we do it only homeopathically and with little effect on the world of the work of art.

Spatial perspective and its temporal equivalent attract us into the world represented by the painting or the story. They awake our interest by simulating the kind of conditions in which our perception - spatial or action-related - feels at home, is ready to give in to immersion.

Once caught, immersed, in the painting or play, we open ourselves to a second facet of our participation in their fictional worlds. We are or quickly become sensitive to the concrete concerns raised by this world, perhaps as sensitive as we are to those present in our own actual world. The most common such concerns relate to ways of acting and coping with action, that is, to the existential, individual, and moral, interactive, concerns highlighted by the painting and the play. And, again, I don't comprehend these existential and moral concerns through an intellectual effort - by reading the preface to Hamlet, for instance -, but I rather grasp them unreflectively, in the heat of the action.

Immersed in the challenges raised by the circumstantial cause (and through it by the mainspring of action) and leading to the highpoint of the tragedy and its resolution, I sense that the actors of the play answer these

4. The notion of immersion was elaborated by Jean-Marie Schaeffer (Pourquoi la fiction?, Paris, Seuil, 1999). 
challenges in accordance with a set of maxims - tacit or explicit - that instruct them how to behave. There are authors whose specialty is a limpid expression of these maxims. Pierre Corneille is one of them, whose characters never make a decision without first articulating a set of moral syllogisms that have the form :

In situation $\mathrm{S}$, an actor belonging to class $\mathrm{C}$, ought to perform action $\mathrm{A}$ $\mathrm{I}$ belong to class $\mathrm{C}$ and find myself in situation $\mathrm{S}$

Therefore I ought to perform action A

Since Corneille's tragedies involve dramatic choices, his characters usually are faced with two incompatible requirements :
A son should revenge an offense suffered by his father.
My father was offended by don Sancho.
I must kill don Sancho.
But
A man cannot kill a parent of his beloved.
Don Sancho is the father of my beloved Chimena.
I cannot kill don Sancho.

Rodrigo's beautiful monologue in Le Cid, II, develops these two moral syllogisms and deplores the difficulty of having to choose among their conclusions.

In Hamlet, the characters are often able to formulate the maxims that should guide their actions, but they are not as ready to follow them as are Corneille's herœs.

\author{
This is most brave \\ That I, the son of a dear father murdered \\ prompted to my revenge by heaven and hell, \\ Must, like a whore, unpack my heart with words... (II, 2, v. 571-574)
}

In Corneille, not rushing to act according to a compelling maxim can only be the effect of an equally forceful maxim. Hamlet's hesitations are not attributable to a struggle between high principles, but to the character's inability to bring himself to act according to the prescription that applies to him. He clearly understands the maxim, but also sense the distance that separates his actions from the precepts meant to guide them. We are not simply maxim-applying beings, Hamlet seems to say, blaming himself for his indecision.

Gradually, in a long and convoluted process, literature abandoned the explicit formulation of guiding maxims and depicted actors who are guided by a silent, inarticulate moral instinct. Henry James' fiction offers a memorable example of this outcome. 
James' characters, incredibly accurate in their moral choices, are never eager to explain them to themselves or to other actors. Why does Isabel Archer, in Portrait of a Lady, appear to want to return to her unworthy husband, Gilbert Osmond? Does she indeed want it? Does she rather decide to devote herself to the happiness of Osmond's natural daughter Pansy? In both cases, Isabel would act out of a strong sense of duty - either social duty to a weak man whom she despises, or personal conviction that she, Isabel, is the only person who would be able to protect Pansy against her irresponsible parents. But Isabel's possible paths and the maxims that she follows are in no way presented to the reader, who is, on the contrary, attracted into the thick of momentary reflections and reactions as if the characters were living from one second to the next without any guiding principles or long term goals. And yet few novelists manage to suggest the moral sturdiness of their characters better than James.

His art consists in making us feel the immersion in the strongest, and I'd say not always a reader-friendly, way. When reading The Portrait of a Lady or The Ambassadors, I attend the events and the characters' thoughts close up and bit by bit. I am required to figure out both the narrative perspective - cause, knot, climax, denouement - and the concrete concerns and principles that guide the characters, from a myriad of tiny juxtaposed items. For a similar case in visual arts, one can consider Adolph Menzel's large, busy paintings The Iron Rolling Mill in the Alte Nationalgalerie, Berlin, or, to some extent, Procession in Hofgastein at the Neue Pinakothek in Munich, which require the viewer to go through a multitude of small figures and local gestures while figuring out the overall orientation of the space and looking for the dramatic center which appears to be fragmented, disseminated around or even, perhaps, non-existent.

James appears to have felt that long term links between narrative beginnings and ends are overstated in older literature. He might have been suspicious of denouements that characters pursue too eagerly and too obviously in accordance to explicit expectations. In The Beast in the Jungle, John Marcher spends his whole life waiting for a mysterious event that would define his destiny. Thirst for a spectacular climax prevents him from noticing that his friend May Bartram is patiently, unobtrusively, expecting him to propose. Having submitted himself early on to an over-dramatic temporal perspective that emphasizes the beginning and the end, he forgets that life consists of the middle.

But something else is at stake as well in James' way of narrating. His « close-up and bit-by-bit » narratives show that not all periods and societies are equally eager to formulate explicitly every precept conducive to action. Reluctance to articulate maxims, or "moral inarticulacy », to use a term introduced by Charles Taylor, doesn't however necessarily mean that the 
moral sense is less prominent ${ }^{5}$. In Le Cid as in Hamlet, the limpidly expressed moral maxims : «A son should revenge an offense against his father; a man cannot kill a parent of his beloved; revenge of a father's death is a son's duty; murdering a usurper, that is, a tyrant, is a commendable feat », rest on a less clearly articulated awareness of the kind of goods that must be pursued. The good in question in both plays is honor, more specifically family honor. Charles Taylor calls hypergoods the kind of higher level goods that govern the specific maxims that lead to practical choices.

Hypergoods, in this case the sense of honor, do not only relate to the lower-level maxims expressed by Rodrigo and Hamlet. A hypergood derives its strength from a more general attitude, from what could be called a worldview, or, more in tune to our present-day language, a space of values (of Goods), whose specific warp, whose curvature, highlights a set of hypergoods. In the case of Hamlet and Le Cid, the sense of honor depends on the more fundamental principle that «life is not the highest good». When we read Le Cid and Hamlet or attend their performance, the multitude of explicit maxims facilitate our access to the hypergoods that govern them and, at the same time, invite us to find our way in the wider space of values (or Goods) that upholds their worth.

One of the differences between our involvement in the world of Hamlet and our immersion in the world of Portrait of a Lady consists in the way we are enticed to adhere to the hypergoods governing these worlds. The absence of well-articulated moral maxims in The Portrait of a Lady does not necessarily mean that this novel portrays a world in which no clear moral principles are shared by all participants to the action ${ }^{6}$ and even less that this world would be affected by some kind of impossibility to formulate universally shared moral principles. The absence of well-articulated moral maxims may just suggest that in the world in question accumulation of reflective experiences alone makes clearer a direct but not all at once bearing of hypergoods, without the intermediary layer of explicit precepts.

Certainly, hypergoods (e.g. honor, uprightness) are not specific enough to be applicable as such. It is not enough to say : "I must be honorable », "I must be upright »; one also needs to know how to be so. When maxims prescribing behavior abound, moral syllogisms like those used by Corneille's characters provide adequate guidance. But in a world in which the orientation in the space of Goods must proceed without the help of clear-cut maxims, in a world, that is, in which individuals are expected to have in their own heart a moral compass whose trembling arrow points to the moral North,

5. The notions of moral inarticulacy and hypergoods are developed in Charles Taylor, The Sources of the Self. The Making of the Modern Identity, Cambridge, Mass., Harvard University Press, 1989.

6. As Robert Pippin argues in his inspiring book Henry James and Modern Moral Life, Cambridge, Cambridge University Press, 2001. 
finding one's path of action requires a silent, bit-by-bit, awareness of the hidden arrow's movements. This is the kind of moral world The Portrait of a Lady and The Ambassadors strive to capture. Isabel Archer, as well as Labert Strether in The Ambassadors, struggles to remain upright in situations in which clearly articulated maxims are not available or not helpful. These characters relentlessly seek the governing Goods within the cloudy night (rather than starry sky) of their own breast. The " close-up and bit-by-bit » technique focuses on their difficult, uninterrupted search for inner equilibrium, for the inner, dark, silent certainty of being right and upright.

\section{Distance and wonder}

If temporal perspective and portrayal of moral concerns attract us, entice us, in the fictional world in such an effective way, it often is because narratives and plays select memorable topics and events, rather than predictable ones. This is true at all times, including the periods most devoted to realist representation of social life. A study of $19^{\text {th }}$-century French and English novels showed that while adultery and divorce is quite frequent in these novels affecting close to half of the fictional main couples that appear in them, in real life only a tiny minority of marriages ended in divorce ${ }^{7}$. Consequently, a divorce was a memorable event, hence its much greater occurrence in novels. We could designate the likelihood of the main conflict in a story to occur in the actual world as « immediate plausibility ». It is rather obvious that this kind of plausibility is not the main object of fictional invention.

Narratives and plays do sometimes take banal, predictable events and attitudes as their object, e.g. many of Maupassant's and Chekhov's stories. Immediate plausibility, moreover, was pronounced by $19^{\text {th }}$ century realism as one of its principal aims, although, in fact, it wasn't necessarily its main achievement. Packing the fictional world with easily recognizable elements is not the same thing as achieving plausibility. In realist literature, in Chekhov, for instance, the easily recognizable elements that make up Uncle Vania are there not just simply in order to be identified as ordinary, but also, and especially, in order to render Sonia and Uncle Vania's kindness and devotion conspicuous, extraordinary. Plausibility cannot be the main - much less the only - aim of fictional world builders. Fictional worlds do use plausibility as props that attract us, entice us, persuade us to get immersed, but immersion is only one side of the game. Fiction's interest in what is memorable, its way of suggesting the distance between our actual world and the fictional one, the out-of-the-ordinary character of the « transport» that takes us there provide the other, equally essential, side of our involvement with fiction.

7. Nathalie Heinich, États de femme. L'identité féminine dans la fiction occidentale, Paris, Gallimard, 1996. 
Getting immersed in a fictional world means, as we saw, getting close to the characters represented within the temporal perspective, acknowledging their plight, their passions, their motives, what makes them tick and act. We vicariously participate in their surrounding world, we fleetingly but vividly belong to their Umwelt (to use an evocative German term whose literal translation would be « about-world »).

But this is not our only move. In order to figure out how and why these characters act, we discern the maxims that orient their choices (e.g. «A son should avenge the murder of his father », " To kill a tyrant is no crime »). We moreover come to grasp - and be moved by - the Governing Goods, the hypergoods which confer these maxims their calling power, things like honor, fidelity, uprightness. And slowly but surely we become aware, we intuit, that in the heart of this Umwelt there lies a spring of values, a font of Goods, which shapes up the Umwelt (the surrounding world) into a fully grown and much vaster Welt, into a world ${ }^{8}$. This vaster world reverberates with principles like « life is not the highest good 》 (prevailing in the Early Modern tragedy) or, in Henry James, " happiness is not the highest good ». And when we sense that the surrounding world becomes a world, we experience an irrepressible wonder. The fictional realm ceases to be a narrow surrounding milieu in which we immerse so well, and becomes the vaster place where we discern a set of Governing Goods and, through them, a pervading worldview. At this level we get a glimpse of what can be called « the Highest Good »-although, certainly, it is not necessarily a direct vision, but rather an interrogative, or even a negative one. Definite statements about it are uttered only to be, in the end, subjected to doubt, as happens in the literary genre that regularly soars to this level - Greek tragedy. There is a passage in Antigone which begins with a celebration of human power and craftiness :

\footnotetext{
Numberless are the world's wonders, but none

More wonderful than man; the stormgray sea

Yields to his prows, the huge crests bear him high;

Earth, holy and inexhaustible, is graven

With shining furrows, where his plow has gone

Year after year, the timeless labor of stallions ${ }^{9}$.
}

This passage ends, however, with a warning against precisely the kind of Good that Antigone will pursue :

8. Joseph Pieper, On Leisure as the Basis of Culture, G. Malsbary (trans.), South Bend, Indiana, St. Augustine's Press, 1998. Pieper gives a new life to the old stoic idea according to which, beyond the perceptible caprices of fate, the wise are able to grasp the logos that rules the world.

9. Sophocles, Antigone, trans. Dudley Fitts and Robert Fitzgerald, in The Oedipus Cycle, New York, A Harvest Book/Harcourt, p. 203-204. 
O fate of man, working both good and evil!

When the laws are kept, how proudly his city stands!

When the laws are broken, what is his city then?

Never may the anarchic man find rest at my hearth,

Never be it said that my thoughts are his thoughts ${ }^{10}$.

For, not unlike the Highest Being in negative theology (a discipline that talks about its object only in a negative, indirect way), the Highest Good is often better grasped by silence or negation. It becomes obvious, in Antigone, that the law of the city and the justice sworn by the gods would in some cases clash with each other. Similarly, it would be wrong to say that in the world of Hamlet honor is the highest good - for it is only one among the Governing Goods. What is then the highest good of Antigone or of Hamlet? I'm not sure we can or need to identify it explicitly. It might suffice to say, negatively, that, in these two tragedies neither the peace of the city, nor life, understood as individual survival, is the highest good. The highest good can only be pinpointed as something that lies above and beyond the Governing Goods, preventing any of them to become ultimate.

Once we reach this insight, we realize that it might apply to our own actual world, to the everyday life we lead. « Apply », however, is not exactly the right term here. The insight that « Civil peace, or Life, is not the highest good » does not constitute a proposition that holds true in this or that world, including ours. It rather is a verbal, approximate, translation of the wondergenerating sense that, above and beyond the multitude of maxims for action and hypergoods that guide them, a highest level opens up that provides the whole space of human action not only with shape and limits, but also with a more fundamental impulse. At this level, the fictional and the actual world become one ${ }^{11}$.

\author{
Thomas Pavel \\ University of Chicago
}

10. Ibid., p. 204.

11. My thanks go to Alexander Nehamas, Robert Pippin, Gideon Rosen, and Ralph Ubl for their generous advice and criticism. Marielle Macé kindly proposed the publication of this rather rough draft. Qu'elle trouve ici l'expression de ma vive gratitude. 